\title{
Distinct functions of quotative markers: Evidence from Meidai Kaiwa Corpus
}

\section{Chad Nilep}

\section{Introduction}

The Japanese joshi or particle to serves as a quotative marker, either indicating the content of quoted speech or thought, or serving related functions such as indirectly attributing ideas to parties other than the speaker (functions of evidentiality) or distancing the speaker from those ideas (hedging, self-mocking, and the like). The particle tte is frequently identified as an informal variant of to, serving identical or nearly identical functions in casual speech. Scholars have suggested that the two forms may have different distribution or function (e.g. Jorden 1990, [1962]; Martin 1975; Okamoto 1995; Hamano 1998), but to date there has been little empirical work to distinguish the two forms using broad-based corpus methods. This paper presents an analysis of the Meidai Kaiwa Corpus, a collection of 129 informal conversations collected in ten prefectures throughout Japan. The data show that both to and tte occur frequently in the conversations. Contrary to the common assertion that tte is the variant of to used in casual speech, this suggests that both particles occur in informal contexts. Furthermore, the data show a clear but non-categorical tendency for the particle tte to appear with verbs of speech, especially iu "say", or at the ends of utterances with no following verb, and for the particle to to appear with verbs of cognition, especially omou "think". This tends to support suggestions by Jorden (1990) and Martin (1975) among others that the former particle indicates speech while the latter indicates the content of thoughts.

\section{Data}

Data come from the Meidai Kaiwa Corpus (Ohso 2003), a collection of transcripts of spontaneous conversations among previously acquainted native speakers of Japanese. The 129 conversations that make up the corpus total approximately 100 hours and 28 minutes of speech. Speakers range in age from early teens to over 90 years old, though precise ages are not recorded. Each conversation involves two, three, or four participants, with the largest proportion of conversational groups dyads. Six conversations involve pairs of men, 78 pairs of women, 13 mixed-gender dyads, 17 groups of three women, ten mixed-gender groups of three participants each, one group of four women, and four mixed-gender groups of four participants each.

Seventy-eight of the conversations that make up the Meidai Kaiwa Corpus were recorded in Aichi Prefecture. Other conversations were recorded in Tokyo $(n=22)$, Hokkaido ( $n=8)$, Gifu $(n=7)$, Kanagawa $(n=5)$, Shizuoka $(n=3)$, Yamanashi $(n=2)$, Niigata $(n=2)$, Kyoto $(n=1)$, and Osaka $(n=1)$ prefectures. 


\section{Methods}

The 129 text files that make up the Meidai Kaiwa Corpus were combined into a single file for processing. When the file was scanned for errors, 431 lines out of 325,086 total lines were found to contain corrupted characters and were removed. The resulting corpus was analyzed and tagged for part-of-speech using the ChaSen morphological analyzer (Matsumoto et al. 1999) in KH Coder (Higuchi 2001).

Part-of-speech analysis classified words as nouns, verbs, adjectives, adjectival nouns, adverbs, or 'other'. The last category includes postpositions and all grammatical particles. Classifying all grammatical particles together has the unfortunate effect of conflating several items that have the same form but distinct functions.

In addition to the quotative particle, a particle marking conditional, sometimes translated as "if", and an associative or conjoining particle, often translated "with" or "and", all have the same surface form, to. Example 1 illustrates the conditional particle; example 2 illustrates the associative particle.

1. F064:スカート、スカート楽しいよね。でも気合 入って ないと、 skirt skirt fun PT but spirit enter NEG TO なんか スカートはけない。

somehow skirt wear-NEG

"Skirts, skirts are fun, right. But if for some reason I don't like it, I can't wear a skirt."

2. F034：あれ、な、妹さん とお母さん 3 人 じゃないの。

that PT young-sister To mother TO 3-people isn't PT

"Wait, like, with younger sister and with mother, that's three people, isn't it?"

In example 1, the conditional particle to indicates the condition (kiai haittenai to "if you don't like it") under which skirts are not worn. In example 2, the associative particle indicates the individuals (imoto-san to okaasan to "with younger sister and mother") associated in the group of three people. These three distinct functions are generally recognized as three different particles with the same surface form.

Since all three particles with the form to and the morphosyntactic class 'other' were counted together, the most common collocate of to was $k a$, as in examples 3-4.

3. F023 : ドールコレクション とか ある って。（】）

doll collection TOKA exist TTE

"There's a doll collection and so on."

4. F048 : サンドイッチとか ケーキとか も あるし。

sandwich TOKA cake TOKA also exist

"There are also sandwiches and cakes and so on." 
While many analyses view the string toka as a combination of the associative particle to and the interrogative particle $k a$, at least historically (Suzuki 1998; Kinuhata 2012), ${ }^{1}$ in contemporary usage toka is often treated as a lexical item in its own right (Kuno 1973). In light of this, part-of-speech tagging was re-run forcing identification of the string toka as a single word.

No other attempt was made to separate the various forms of to with automatic parsing or part-of-speech tagging. ${ }^{2}$

The final tagged corpus database consists of 3,656,677 tokens of 22,178 word types. It features 21,346 tokens of the particle tte and 27,827 tokens of to (conflating all uses). Using KH Coder, the most frequent collocates of each string were identified.

The second-most common item following the particle tte (the R1 collocate, first item to the right) and third-most common following to is the full-stop, accounting for $14.19 \%$ of R1 collocates of tte and $5.79 \%$ of to. Since it occurs at the end of an orthographic sentence, the full-stop is useful for identifying sentence-final occurrences of the particles. The transcription is not consistent in using full-stops at the end of sentences, however. Question marks, parenthesis or angled brackets enclosing transcribers' notes, as well as other marks of punctuation also sometimes occur at the end of an utterance or turn at talk. Therefore all marks of punctuation were grouped together as a single category in counting R1 collocates. ${ }^{3}$ The resulting category "all punctuation" occurred as the most common R1 collocate of tte and the second most common R1 collocate of to.

\section{Results}

The most common item following the particle tte was punctuation, accounting for $28.35 \%$ of R1 collocates. The second most common item was the verb iu "say" at $17.01 \%$ of R1 collocates. The ten most common items are summarized in Table 1.

\footnotetext{
${ }^{1}$ Additionally, some scholars view toka as a grammaticalized quotative marker derived from the quotative to. An analysis of ten randomly selected tokens of toka from the corpus found only tokens of the associative to $+k a$, though a more systematic search might reveal quotatives as well.

2 Another common collocate of to, the verb ikeru "do, can do" (see Table 4), is similarly problematic. In every case that the parser recognized as to followed by the verb ikeru, the form of the verb is negative (e.g. yaranai to ikenai). The string 'negative + to ikenai' is a conventionalized marker of obligation (Fujii 2004).
}

${ }^{3}$ Punctuation marks following tte or to are the following, in order of frequency:

$* \quad<-\Gamma$ 
Table 1 Right-collocates of tte

\begin{tabular}{|l|r|r|}
\hline word type & \multicolumn{1}{|c|}{ tokens } & \multicolumn{1}{c|}{ percent } \\
\hline punctuation & 6,052 & 28.35 \\
\hline 言う “say” & 3,631 & 17.01 \\
\hline こと “thing” & 879 & 4.12 \\
\hline 感じ “feeling” & 574 & 2.69 \\
\hline 思う “think” & 558 & 2.61 \\
\hline
\end{tabular}

\begin{tabular}{|l|r|r|}
\hline word type & \multicolumn{1}{|c|}{ tokens } & \multicolumn{1}{l|}{ percent } \\
\hline の nominal & 385 & 1.80 \\
\hline 書く “write” & 306 & 1.43 \\
\hline 何 “what” & 278 & 1.30 \\
\hline ね interaction & 266 & 1.25 \\
\hline 聞く "listen” & 199 & 0.93 \\
\hline
\end{tabular}

Among verbs following the particle tte, the verb iu "say" is by far the most common, accounting for $64.25 \%$ of verb collocates and $17.01 \%$ of all collocates. The second most common verb is the cognition verb omou "think", accounting for $9.87 \%$ of verb collocates. The third and fourth most common verb collocates, kaku "write" (5.41\%) and $k i k u$ "hear" (3.52\%) are, like $i u$, verbs suggesting verbal communication. The ten most common verb collocates of tte are summarized in Table 2.

Table 2 Verb right-collocates of tte

\begin{tabular}{|l|r|r|}
\hline word type & \multicolumn{1}{|c|}{ tokens } & \multicolumn{1}{c|}{ percent } \\
\hline 言う “say” & 3,631 & 64.25 \\
\hline 思う “think” & 558 & 9.87 \\
\hline 書く“write” & 306 & 5.41 \\
\hline 聞く“listen” & 199 & 3.52 \\
\hline 知る “know” & 96 & 1.70 \\
\hline
\end{tabular}

\begin{tabular}{|l|r|r|}
\hline word type & \multicolumn{1}{|c|}{ tokens } & \multicolumn{1}{|c|}{ percent } \\
\hline 感じる “feel” & 60 & 1.06 \\
\hline 出る “go out” & 50 & 0.88 \\
\hline 呼ぶ “call” & 39 & 0.69 \\
\hline 食べる “eat” & 38 & 0.67 \\
\hline 行う “do” & 30 & 0.53 \\
\hline
\end{tabular}

The most common item following the particle to is the verb omou "think", which accounts for $27.56 \%$ of $\mathrm{R} 1$ collocates. The second most common item is the combined category of punctuation with $24.00 \%$ of collocates. The words issho "together, same" $(1.07 \%)$ and onaji "same, identical" $(0.55 \%)$ were among the ten most common R1 collocates of to. Each of these words is likely to follow the associative particle to "and, with" rather than the quotative, as illustrated in examples 5-6.

5. F021:でも嫁 に 行ってさ一、親 と一緒 にうまくできる but bride LOC going PT parent TO together LOC well do

"But if she gets married, you know, can she get along with his parents"

6. オペラ歌手 と同じように歌わないでー、でも 発声はきちんとやってね。 opera-singer TO same so-as sing-NEG but utter TOP precise do PT "Don't sing the same as an opera singer, but vocalize precisely, you know." 
Table 3 Right-collocates of $t o$

\begin{tabular}{|l|r|r|}
\hline word type & \multicolumn{1}{|c|}{ tokens } & \multicolumn{1}{c|}{ percent } \\
\hline 思う “think” & 7,670 & 27.56 \\
\hline punctuation & 6,678 & 24.00 \\
\hline は topic & 627 & 2.25 \\
\hline ね interaction & 539 & 1.94 \\
\hline 一緒 “together” & 299 & 1.07 \\
\hline
\end{tabular}

\begin{tabular}{|l|r|r|}
\hline word type & \multicolumn{1}{|c|}{ tokens } & \multicolumn{1}{c|}{ percent } \\
\hline 言う“say” & 286 & 1.03 \\
\hline いける “do” & 158 & 0.57 \\
\hline 同じ “same” & 153 & 0.55 \\
\hline も“also” & 123 & 0.44 \\
\hline だめ “cannot” & 117 & 0.42 \\
\hline
\end{tabular}

The verb ikeru "do, be able to do" $(0.57 \%)$ is also among the ten most common verbs. In every case where ikeru follows to, the form of the verb is the negative ikenai, as illustrated in examples 7 and 8. The string (verb) to ikenai indicates prohibition; when the initial verb is negative, as was the case in $89.94 \%$ of to ikenai tokens in the corpus, the string indicates deontic modal obligation.

7. いちばん早い人 $人$ は 6 時 過ぎから もう いて、子どもが first early person TOP six pass from already be child PT 来るといけないからさ一。 come TO can't from PT

"The first people have already come after six, since children can't come."

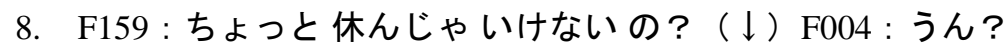

$$
\text { little rest can't PT yes }
$$

F159：通しじゃないといけないの?

$$
\text { straight NEG TO can't PT }
$$

"Can't you rest a bit." "What?" "Do you have to go straight through?"

The ten most common R1 collocates in the data are summarized in Table 3.

Among verbs following the particle to, the verb omou "think" is extremely common, comprising $81.32 \%$ of verb collocates $(27.56 \%$ of all R1 collocates). The communication verb $i u$ "say" is the second most common verb following the particle, but it accounts for only $3.03 \%$ of verb collocates (1.03\% of all R1 collocates). The ten most common verb collocates of to are summarized in Table 4.

\section{Discussion}

It is frequently asserted that tte is equivalent with to, differing primarily in formality (e.g. Hayashi 1997; Shinmura 1998; Kaiser et al. 2001). That is, tte occurs only in 
Table 4 Verb right-collocates of $t o$

\begin{tabular}{|l|r|r|}
\hline word type & \multicolumn{1}{|c|}{ tokens } & \multicolumn{1}{c|}{ percent } \\
\hline 思う “think” & 7,670 & 81.32 \\
\hline 言う “say” & 286 & 3.03 \\
\hline 違う “differ” & 98 & 1.03 \\
\hline 話す “talk” & 77 & 0.82 \\
\hline 行く “go” & 66 & 0.70 \\
\hline
\end{tabular}

\begin{tabular}{|l|r|r|}
\hline word type & \multicolumn{1}{|c|}{ tokens } & \multicolumn{1}{c|}{ percent } \\
\hline 見る “look” & 60 & 0.64 \\
\hline 出る “go out” & 45 & 0.48 \\
\hline 書く“write” & 44 & 0.47 \\
\hline $\begin{array}{l}\text { 比べる } \\
\text { “compare” }\end{array}$ & 43 & 0.46 \\
\hline 会う “meet” & 40 & 0.42 \\
\hline
\end{tabular}

colloquial or casual speech while to may be used with various levels of formality. Analysis of a corpus of conversations among acquaintances shows the frequent use of both tte and to. While it is difficult to specify the degree to which particular uses are colloquial or casual with broad-based corpus methods, the Meidai Kaiwa Corpus consists of conversation among previously acquainted speakers with no researcherspecified topics. Such data collection methods tend to produce less formal types of speech. While these data can say nothing conclusive about the relative level of formality of to and tte, they reveal that each particle is used in friendly conversation.

\subsection{Particle-verb collocation patterns}

The data further suggest that tte and to are not utilized in identical contexts. Although each particle can be followed by the verb iu "say" and each can be followed by the verb omou "think", there is a strong tendency to prefer the collocation tte iu $(3,631$ occurrences) over to iu (286 occurrences), and likewise to prefer to omou (7,670 occurrences) over tte omou (558 occurrences). This is consistent with speaker intuitions reported to Martin (1975) that tte is used to mark reported speech as opposed to the content of thoughts. As Martin noted, however, his informants' observations were overly categorical: despite the strong preference for to, tte does occur with omou to mark the content of thoughts. Examples from the data include 9-10.

9. F060: こう、空間 も ねー（うん）うまく使ってるって思う。（】）（ほ一）うん。 here space also PT (yeah) well using TTE think ho yeah

"Here, this space too, right, [yeah] they're using it well, I think. [oh] Yeah."

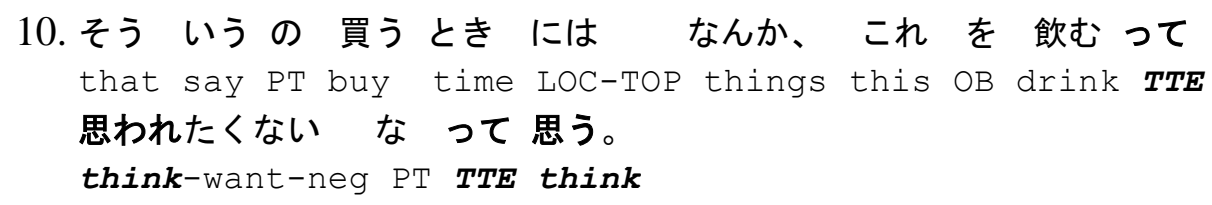

"When I buy that stuff, like, I think, 'I don't want them to think I drink this'." 
Table 5 Quotatives following omou "think"

\begin{tabular}{|l|r|r|}
\hline $\begin{array}{l}\text { quotative } \\
\text { +verb }\end{array}$ & tokens & percent \\
\hline $\begin{array}{l}\text { と思う } \\
\text { (to omou })\end{array}$ & 7,670 & 93.22 \\
\hline $\begin{array}{l}\text { って思う } \\
\text { (tte omou })\end{array}$ & 558 & 6.78 \\
\hline
\end{tabular}

The corpus includes 7,670 occurrences of the string to omou compared to just 558 occurrences of tte omou. Thus, in $93.22 \%$ of cases of quotative + omou, the quotative particle is to (see Table 5). The preference for to in such constructions is very great, but not categorical. The examples cited above show no sign of disfluency or other indications that tte omou constitutes a speech error or an ungrammatical utterance.

The frequency of to omou appears to confirm the notion that to is the preferred marker for the content of thoughts, as suggested by both Jorden (1990 [1962]) and Martin (1975). Two other verbs complicate this idea, however. The verbs kangaeru "consider" and kimaru "decide", can also occur with a clause or phrase indicating the content of thoughts. The strings to kangaeru and tte kangaeru each occur 14 times in the corpus. Such usage is illustrated in examples 11 and 12.

11. M023：明日 休む と 考えた だけで、こんな時間まで起きてられる。 tomorrow rest To consider only this time until rise

"Only by thinking, 'Tomorrow is a day off,' (I) can stay up this late."

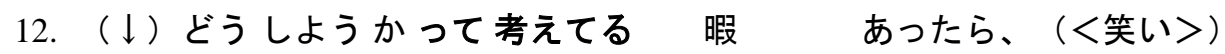

$$
\begin{aligned}
& \text { what do Q TTE consider leisure exist (laugh) }
\end{aligned}
$$

The string to kimaru occurs eight times, while tte kimaru occurs ten times. Usage is illustrated in examples 13 and 14.

13. 何か 28 で相手 と 決まっても、結婚 できるのはちょっと遅れて what 28 LOC partner TO decide also marry do TOP little be-late "Like, even if you decide on a partner at 28, it's a little late to get married"

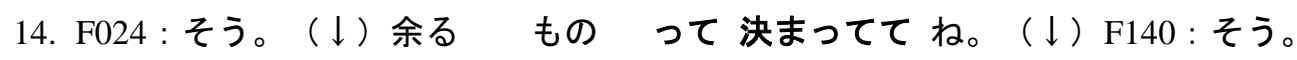

$$
\begin{aligned}
& \text { so remain thing TTE decide } \mathrm{PT} \text { so }
\end{aligned}
$$

"Right. It has been decided which things to leave out." "Right."

The verbs kangaeru and kimaru do not show the strong tendency for occurrence with to that was observed with the verb omou. This suggests a possibility that the quotative to has an affinity specifically for the verb omou rather than for marking the content of 
thought generally. Given the small number of occurrences of each verb, however, strong conclusions may not be warranted.

As the verb omou shows a strong tendency to occur with to, the verb iu "say" tends to occur with the quotative tte. The corpus includes 3,631 occurrences of the string tte iu and 286 occurrences of to $i u$. This means that in $92.70 \%$ of quotative $+i u$ cases, the quotative is tte. Moreover, this tendency is also seen with other verbs indicating communication. Quotative particles to and tte occur with the verbs kaku "write", kiku "hear", yobu "call", and hanasu "speak". As shown in Table 6, the tendency holds for most verbs of communication. In cases of quotative + communication-verb, the particle is overwhelmingly tte ( $90.47 \%$ of combined cases).

\section{Table 6 Particles following communication verbs}

\begin{tabular}{|l|r|r|l|}
\hline verb & \multicolumn{1}{l|l}{ tte } & \multicolumn{1}{l|}{ to } & \% tte \\
\hline 言う (say) & 3,631 & 286 & 92.70 \\
\hline 書く(write) & 306 & 44 & 87.43 \\
\hline 聞く (hear, ask) & 199 & 25 & 88.84 \\
\hline 呼ぶ (call) & 39 & 9 & 81.24 \\
\hline 話す (talk) & 13 & 77 & 14.44 \\
\hline
\end{tabular}

There is one apparent exception to this pattern. The verb hanasu "speak, converse" frequently occurs with to; the string to hanasu is nearly six times as frequent as tte hanasu. This appears to be an artefact of conflating associative to with quotative to. In most cases within the data, to hanasu appears to indicate a person or group spoken to, as illustrated in examples 15 and 16.

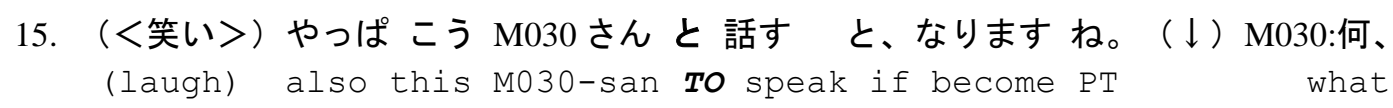
"After all, (you) get that way if you speak to Mr. (M030)." "What?"

16. 年上の 人 とかいんな 世界の人 と 話さなきやだめ だ という。 elder person TOKA various world person TO speak-must COP say

"They say you must speak with older people and various people of the world."

Of the 77 occurrences of the string to hanasu, 13 are preceded by the honorific san "Mr., Ms." and another four by chan, a diminutive variant of san used for children or intimates. Forty-five of the 77 occurrences follow a noun, with the most common tokens hito "person" (13), sensei "teacher" (10), kodomo "child" (6), and tomodachi "friend" (5). In other words, the string to hanasu usually indicates the person with whom one is speaking - a use of the associative particle to - and not the content of the speech. 


\subsection{Particles in sentence-final position}

While Japanese quotative particles often occur before a verb indicating speech or thought, they can also occur at the end of a sentence or utterance. Sentence-final occurrences may indicate direct or indirect quotations in much the same way that quotative + verb combinations do. In addition, such usage can have serve pragmatic functions such as distancing a speaker from the ideas expressed, marking evidentiality, or marking as topic some idea not overtly expressed in the preceding discourse (Okamoto 1995; Nilep and Fujimoto 2003; Suzuki 2007, inter alia). Some scholars (e.g. Martin 1975; Tanaka 2001) have suggested that sentence-final tte may be a reduced form of a construction containing a verb, such as tte itte (quotative tte plus a non-finite inflected form of the verb iu "say"), though this suggestion remains somewhat controversial. While the methods employed here can shed little light on that controversy, by examining occurrences of to or tte before punctuation it is possible to approximate the relative frequency of each particle in sentence-final position.

As noted above, the combined category of all punctuation is the most common rightcollocate of tte and the second most common following to. Furthermore, the raw number of occurrences is similar, with 6,052 tokens of tte followed by punctuation compared to 6,678 tokens of to. At first glance, this seems to suggest that the particles are more or less equally common in sentence-final position. However, as was noted above, the morphological analysis used here conflates forms that may be semantically and morphologically distinct but written or pronounced similarly. Therefore, close inspection of to or tte followed by punctuation is needed.

To facilitate close inspection, a random selection was made from the instances of each particle followed by punctuation. First, all keywords in context (KWIC) in which to is followed by a mark of punctuation were combined into one list using Microsoft Excel. From this list of 6,678 KWIC, fifty were randomly selected. Each selection was then analyzed and coded as either containing the quotative particle, the associative particle, some other occurrence of orthographic to, or in cases where the function was unclear coded as "uncertain". The same procedure was followed for fifty randomlyselected KWIC in which tte is followed by punctuation.

Of the fifty KWIC containing to, only two were judged to be instances of the quotative particle, shown as examples 17 and 18.

\footnotetext{
17. 大学 受けるときに、（うん）何か 経済 とか法科とか違うな 違う college join time LOC (yeah) what econ TOKA law TOKA wrong PT wrong なと（うん）思ってて、（うん）で、ま、美大 の 建築 か、 PT TO (yeah) thinking (yeah) and um art-school PT architect PT "When (I) go to college [yeah] (I'm) thinking, [yeah] 'not economics, not law, [yeah] so maybe architecture at an art school"
} 


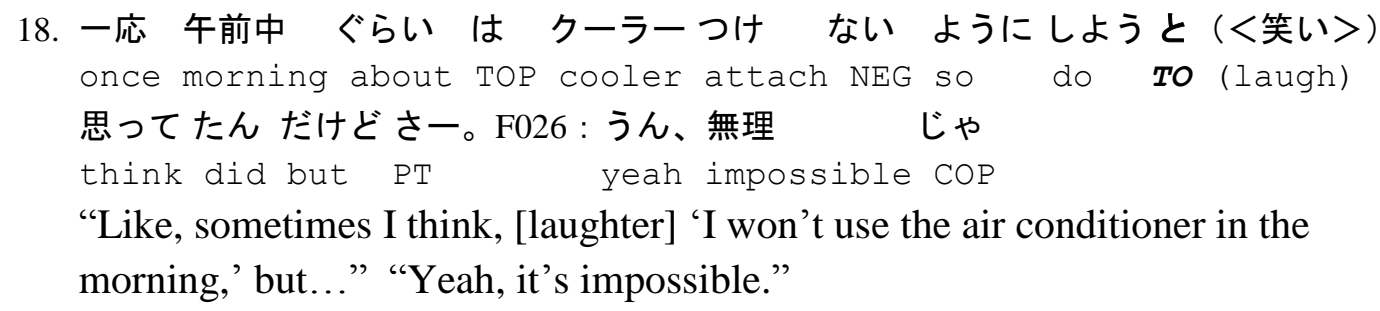

"Like, sometimes I think, [laughter] 'I won't use the air conditioner in the morning,' but..." "Yeah, it's impossible."

In each of these cases, although the quotative to is followed by a mark of punctuation, neither is actually in sentence-final position. In each case, the punctuation following the quotative particle is a left-parenthesis, used to indicate overlapping speech from another speaker. Following the parenthetical overlap, each quotative is followed by the verb omou. Thus, at least in the $50 \mathrm{KWIC}$ analyzed, to followed by punctuation does not actually indicate a quotative in sentence-final position.

One of the occurrences of to followed by punctuation which was coded as uncertain does appear to be serving a function similar to the functions of sentence-final quotatives enumerated above. It is shown as example 19.

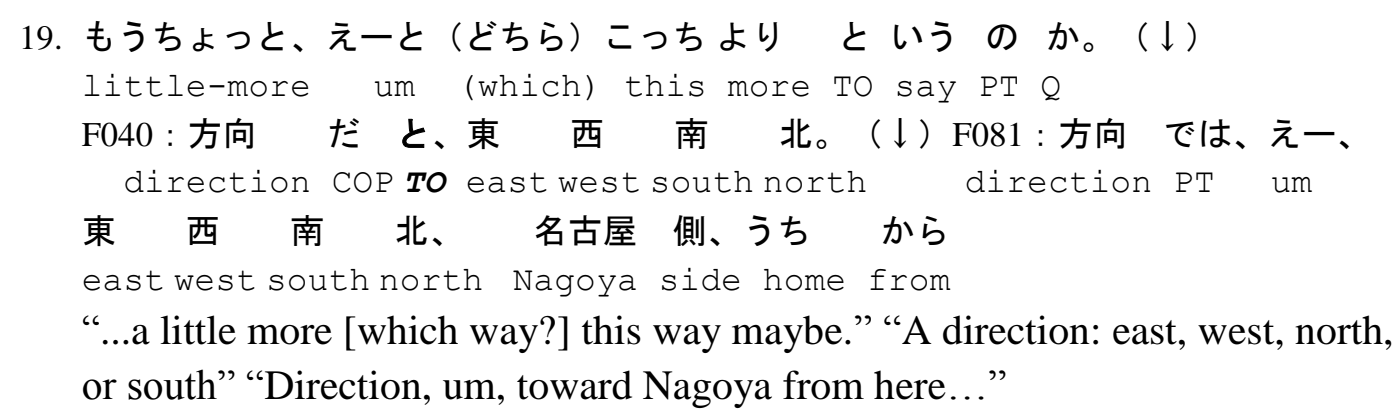

In this utterance, houkou da to, touzainanboku "A direction [to], east, west, north, or south," the particle to may mark the word houkou "direction, orientation," as the topic of the discussion, one of the enumerated functions of sentence-final quotative particles. It seems equally valid, though, to see the function of to in this utterance not as quotative but as a conditional, like those described below.

The conditional to, frequently translated as 'if', marks a possible or likely event or outcome. Thirteen of the $22 \mathrm{KWIC}$ coded as "other" are uses of the conditional to, as illustrated in 20 .

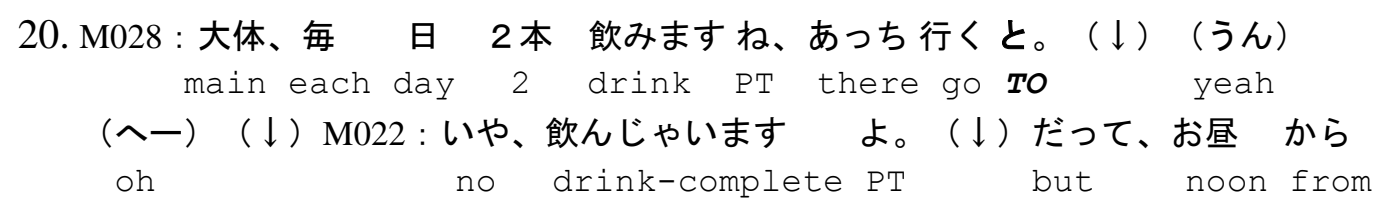

"Pretty much everyday I drink two bottles, if I go there." "Yeah" "Oh" "Really, I drink a lot, you know. Like, from afternoon..." 
In example 20, mainichi ni-hon nomimasu, acchi iku to "I drink two bottles a day if I go there," the particle to indicates the condition that results in the speaker drinking. Returning to example 19, in the string houkou da to "(if) it is a direction", the particle to can be analyzed as marking a condition in which directions must be given, or naming "orientation" as the topic, or serving both functions.

Within the $50 \mathrm{KWIC}$ analyzed with to followed by a mark of punctuation, none are clear examples of the quotative in sentence-final position. It is possible that some number of tokens serve functions similar to those described, for example, by Hayashi (1997) for quotative to in sentence-final position. But given the frequency of conditional or associative function in the KWIC analyzed, that number is presumed to be relatively small.

While sentence-final to revealed a range of uses and arguably includes three distinct particles, sentence-final tte is much more unified. Thirty of the fifty KWIC analyzed were clearly quotative markers, as illustrated in 21 .

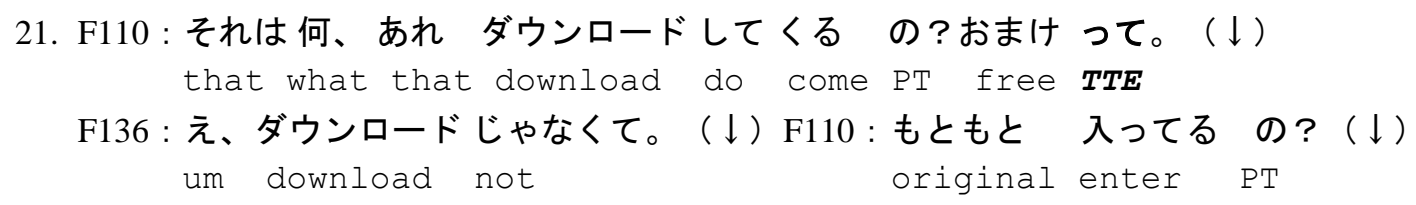

"What is that, did you download it for me? Free, you say." "Um, not downloaded." "Was it already there before?"

Only nine instances had clear non-quotative functions. These were primarily verb inflections that the morphological analyzer identified as separate lexical items, as shown in 22 .

22. （そうなん だ）うん、あの ほら、インターネットホームページ作りたい とか that what COP yeah that look internet homepage make-want TOKA 言って。（よ）（うんうん）でー、その一、あの一、何だっけ、えー、ディスプレイ say-TTE yeah yeah and that that what um display "Is that so." "So, look, like, if (you) say, 'I want to make a web page."” "right, right" "and, um, that display..."

The eleven remaining KWIC coded as uncertain appear to reflect a mixture of quotatives, inflections, and artefacts owing to transcription conventions, errors, or inconsistencies. Example 23 illustrates one such unanalyzable token.

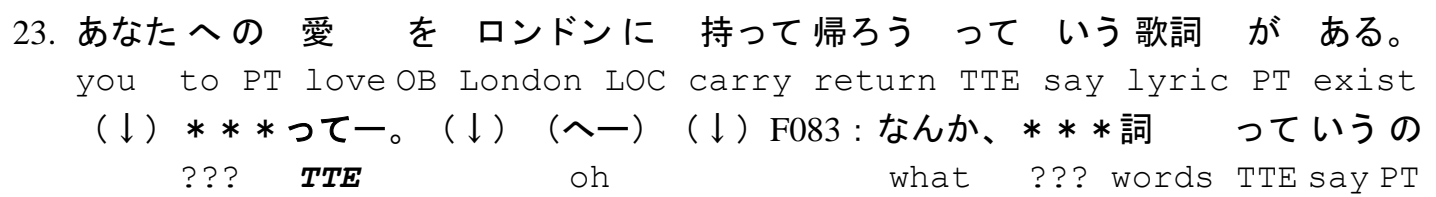
"There are lyrics about wanting to bring your love home to London. ***" "Oh" "What, *** words..." 
Note that, while there are several tokens of quotative tte in example 23 , it is the bold faced element, tte preceded by three asterisks and followed by a bar, that was randomly selected for analysis. Given the asterisks, marking an omission, and the other idiosyncrasies of this fragment, the function of tte is unclear.

Although there is no guarantee that the analyzed cases are typical, if the proportion of quotative and other functions seen in these one hundred key words in context are representative of the 6,052 tokens of tte and 6,678 tokens of to followed by punctuation in the corpus, then once again a similar pattern emerges. There is a clear and strong preference for quotative tte rather than to at the end of sentences, though to may also appear occasionally. As with verbs of communication and verbs of thought, there are clear patterns, but the patterns are not categorical. Table 7 shows the number of each particle type followed by punctuation observed in the 50 KWIC analyzed. The number in parenthesis is the estimated number of each particle type in the entire corpus, if these proportions are consistent. The latter numbers should, of course, be viewed skeptically. Furthermore, as shown above, the presence of punctuation does not necessarily indicate the end of an utterance. The estimated frequency of quotative tte followed by punctuation (approximately 3,631) is virtually the same as the observed frequency of tte followed by the verb iu $(3,631)$. In contrast, the estimated frequency of to followed by punctuation (267 unambiguous quotatives plus 2,671 uncertain cases) is far less than the observed cases of to omou $(7,670)$.

Table 7 Particles followed by punctuation

\begin{tabular}{|ll|r|r|r|r|}
\hline & & \multicolumn{1}{l|}{ quotative } & associative & uncertain & \multicolumn{1}{l|}{ other } \\
\hline$っ て$ & $($ tte $)$ & 30 & 0 & 11 & 9 \\
& & $(3,631)$ & $(0)$ & $(1,331)$ & $(1,089)$ \\
\hline$と$ & $(t o)$ & 2 & 6 & 20 & 22 \\
& & $(267)$ & $(801)$ & $(2,671)$ & $(2,938)$ \\
\hline
\end{tabular}

\section{Conclusion}

An analysis of the more than 100 hours of multi-party conversation in the Meidai Kaiwa Corpus reveals that the quotative particles to and tte show clear and distinct cooccurrence patterns. When referring to the content of thought, the particle to is overwhelmingly preferred, most often appearing with the verb omou "think". When referring to verbal communication, including direct and indirect quotation, the particle tte is preferred, most often followed by the verb iu "say". When a quotative particle occurs at the end of a sentence and no verb follows, again the particle tte is strongly preferred. These preferences are very large; to omou is more than ten times as common as tte omou, while tte iu is more than ten times as common as to iu. Likewise, analysis 
of a random selection of sentence-final particles suggests that tte is fifteen times as frequent as the quotative to before a mark of punctuation, though the analysis also reveals that the presence of punctuation does not necessarily indicate the end of an utterance.

Despite the strength of the patterns revealed, however, these preferences are not categorical rules. There is no suggestion that less common strings such as tte omou are ungrammatical. These patterns confirm empirically some native-speaker and nonnative-speaker analyst intuitions about the particles' usage (Jorden 1990 [1962]; Martin 1975). They are also consistent with the results shown for a much smaller and more closely analyzed corpus by Nilep and Fujimoto (2003).

In addition to the empirical findings, this study reveals some difficulties inherent in the use of morphological parsers, which are necessary for large-scale corpus study. Because all grammatical particles were classified as part of the same category, orthographically and phonetically similar forms such as quotative, associative, and conditional particles (to) could not be distinguished. This suggests two problems to be overcome, one technical and one theoretical.

The technical issue relates to a possible problem of circularity. The current author is not trained in the technical design of parsers or morphological analyzers. However, in theory such systems generally rely on two elements: a lexicon of words and morphemes, and a set of morphosyntactic and morphophonological rules which apply to them. If multiple words have the same form, they must be distinguished primarily by syntactic role. In the case of Japanese particles, word order or other surface markers of syntactic role also partially overlap. It would seem that care must be taken in specifying syntactic rules that are sufficiently specific to distinguish one particle from another, and yet are not so over-specified that they fail to identify relevant instances. To state the risk of circularity concretely, over-specifying the morphosyntactic contexts in which a particle can occur risks only finding instances that support current models of grammar. This in turn risks missing empirical evidence from corpus methods that might allow refinement of those models.

The related problem for linguistic theory is no less thorny. This analysis has assumed that the quotative, associative, and conditional particles are homonyms, distinct forms within the lexicon that share surface form. However, it is sometimes difficult to draw clear lines between these forms. Consider, for example, the following utterance, adapted from Takanashi $(2011,244-245)$ with original morpheme gloss.

24. 名前で 呼んだりとか。たまに でも私も ベイビイとか 呼んじゃう。 name by call or sometimes but I too 'baby' $\boldsymbol{Q T}$ call

"I call him by name, or... But sometimes I also call (my boyfriend) 'baby'." 
Takanashi glosses the first instance of toka as "but" and the second instance as a quotative marker (glossed QT). While the analysis of corpus data above discarded all instances of toka as a lexical item distinct from the quotative, Takanashi's analysis suggests that some tokens of toka may consist of the quotative to combined with the interrogative $k a$. Takanashi is far from alone in this analysis. Other scholars have likewise viewed some instances of toka (Suzuki 2002; Koike 2010) or dato (Okamoto 1995; Suzuki 2007) as quotative markers. One can posit that two homophones pronounced to followed distinct paths to lexicalization as toka, resulting in another pair of homophones. However, it is equally possible to posit a single to particle that is sufficiently vague (Geeraerts 1993) to function as quotative, associative, or conditional, depending on context. In short, it is not clear whether these occurrences of to represent either a set of distinct, homophonous particles or a single, highly polysemous particle.

The problem of polysemy (multiple meanings of a single lexical item) versus homophony (distinct lexical items with the same phonological form) is a vexed one in linguistics (Nunberg 1979; Geeraerts 1993; Brown 2008, inter alia). In the absence of theoretical or philosophical agreement about the nature of lexical meaning, technical solutions to the issues presented here are likely far off.

\section{References}

Brown, Susan Windisch. 2008. "Polysemy in the mental lexicon." Colorado Research in Linguistics no. 21:1-12.

Fujii, Seiko. 2004. "Lexically (un)filled constructional schemes and construction types: The case of Japanese modal conditional constructions." In Construction Grammar in a Cross-Language Perspective, edited by Mirjam Fried and Jan-Ola Östman, 121-155. Amsterdam: John Benjamins.

Geeraerts, Dirk. 1993. "Vagueness's puzzles, polysemy's vagaries." Cognitive Linguistics no. 4 (3):223-272.

Hamano, Shoko. 1998. The Sound-Symbolic System of Japanese. Edited by Masayoshi Shibatani. Vol. 10, Studies in Japanese Linguistics. Stanford: CSLI.

Hayashi, Makoto. 1997. "An exploration of sentence-final uses of the quotation particle in Japanese spoken discourse." In Japanese/Korean Linguistics 6, edited by Ho-min Sohn and John Haig. Stanford: CSLI.

Higuchi, Koike. 2001. KH Coder. http://khc.sourceforge.net/en/.

Jorden, Eleanor Harz. 1990. Beginning Japanese. 14th ed. Tokyo: Charles E. Tuttle. Original edition, 1962.

Kaiser, Stefan, Yasuko Ichikawa, Noriko Kobayashi, and Hilafumi Yamamoto. 2001. Japanese: A Comprehensive Grammar. London and New York: Routledge.

Kinuhata, Tomohide. 2012. "Historical development from subjective to objective meaning: evidence from the Japanese question particle ka." Journal of Pragmatics no. 44 (67):798-814. doi: 10.1016/j.pragma.2012.03.004.

Koike, Chisato. 2010. An analysis of shifts in participation roles in Japanese storytelling in terms of prosody, gaze, and body movements. Paper read at The twenty-seventh annual meeting of the Berkeley Linguistics Society, at Berkeley.

Kuno, Susumu. 1973. The Structure of the Japanese Language. Edited by Samuel Jay Keyser, Current Studies in Linguistics. Cambridge, MA: MIT Press.

Martin, Samuel E. 1975. A Reference Grammar of Japanese. New Haven: Yale University Press. 
Matsumoto, Yuji, Akira Kitauchi, Tatsuo Yamashita, Yoshitaka Hirano, Hiroshi Matsuda, Kazuma Takaoka, and Masayuki Asahara. 1999. Japanese Morphological Analysis System ChaSen 2.0. Nara Institute of Science and Technology, Nara.

Nilep, Chad, and Junko Fujimoto. 2003. Animating functions of quotative particles to and tte in spoken Japanese. In JSLS 2003 The 5th Annual Conference of the Japan Society for Language Science, edited by Tamiko Ogura. Kyoto University: JSLS.

Nunberg, Geoffrey. 1979. "The non-uniqueness of semantic solutions: polysemy." Linguistics and Philosophy no. 3 (2):143-184.

Ohso, Mieko. 2003. 名大会話コーパス [Meidai Kaiwa Corpus]. Tokyo: National Institute for Japanese Language and Linguistics.

Okamoto, Shigeko. 1995. "Pragmaticization of meaning in some sentence-final particles in Japanese." In Essays in Semantics and Pragmatics: In Honor of Charles J. Filmore, edited by Masayoshi Shibatani and Sandra Thompson, 218-246. New York and Amsterdam: John Benjamins.

Shinmura, Izuru. 1998. 広辞苑 [Koujien dictionary]. Tokyo: Iwanami.

Suzuki, Satoko. 1998. "Pejorative connotation: a case of Japanese." In Discourse Markers: Descriptions and Theory, edited by Andreas Jucker, 261-276. New York and Amsterdam: John Benjamins.

. 2002. "Self-mockery in Japanese." Linguistics: An Interdisciplinary Journal of the Langauge Sciences no. 40 (1):163-189.

2007. "Metapragmatic function of quotative markers in Japanese." In Metapragmatics in Use, edited by Axel Hübler and Wolfram Bublitz, 73-85. Amsterdam: John Benjamins.

Takanashi, Hiroko. 2011. "Complementary stylistic resonance in Japanese play framing." Pragmatics no. 21 (2):231-264.

Tanaka, Hiroko. 2001. The implementation of possible cognitive shifts in Japanese conversation. In Studies in Interactional Linguistics, edited by Margaret Selting and Elizabeth Couper-Kuhlen. Amsterdam/Philadelphia: John Benjamins.

\section{Appendix: Transcription conventions}

TO any instance of to

TTE any instance of tte

TOKA any instance of toka

COP copula

LOC locative postposition
NEG negative inflection

OB object marker $o$

Q interrogative marker

TOP topic marker $w a$

PT other particles not specifically analyzed 